\title{
Waste to energy plant operation under the influence of market and legislation conditioned changes
}

Tomic, Tihomir ; Dominkovic, Dominik Franjo; Pfeifer, Antun; v, Daniel Rolph ; Pedersen, Allan Schrøder; Dui, Neven

\section{Published in:}

Energy

Link to article, DOI:

10.1016/j.energy.2017.04.080

Publication date:

2017

Document Version

Peer reviewed version

Link back to DTU Orbit

Citation (APA):

Tomic, T., Dominkovic, D. F., Pfeifer, A., v, D. R., Pedersen, A. S., \& Dui, N. (2017). Waste to energy plant operation under the influence of market and legislation conditioned changes. Energy, 137, 1119-1129. https://doi.org/10.1016/j.energy.2017.04.080

\section{General rights}

Copyright and moral rights for the publications made accessible in the public portal are retained by the authors and/or other copyright owners and it is a condition of accessing publications that users recognise and abide by the legal requirements associated with these rights.

- Users may download and print one copy of any publication from the public portal for the purpose of private study or research.

- You may not further distribute the material or use it for any profit-making activity or commercial gain

- You may freely distribute the URL identifying the publication in the public portal 
WASTE TO ENERGY PLANT OPERATION UNDER THE INFLUENCE OF MARKET AND LEGISLATION CONDITIONED CHANGES

\author{
Tihomir Tomić*
}

University of Zagreb, Faculty of Mechanical Engineering and Naval Architecture address: Ivana Lučića 5, 10002 Zagreb, Croatia

e-mail: tihomir.tomic@fsb.hr

\section{Dominik Franjo Dominković}

Department of Energy Conversion and Storage, Technical University of Denmark (DTU) Frederiksborgvej 399, 4000 Roskilde, Denmark e-mail:dodo@dtu.dk

Antun Pfeifer

SDEWES Centre

address: Ivana Lučića 5, 10002 Zagreb, Croatia

e-mail: antun@sdewes.org 
Allan Schrøder Pedersen

Neven Duić

\section{ABSTRACT}

In this paper, gate-fee changes of the waste-to-energy plants are investigated in the conditions set by European Union legislation and by the introduction of the new heat market. Waste management and sustainable energy supply are core issues of sustainable development of regions, especially urban areas. These two energy flows logically come together in the combined heat and power facility by waste incineration. However, the implementation of new legislation influences quantity and quality of municipal waste and operation of waste-toenergy systems. Once the legislation requirements are met, waste-to-energy plants need to be adapted to market operation. This influence is tracked by the gate-fee volatility. The operation of the waste-to-energy plant on electricity markets is simulated by using EnergyPLAN and heat market is simulated in Matlab, based on hourly marginal costs. The results have shown that the fuel switch reduced gate-fee and made the facility economically viable again. In the second case, the operation of the waste-to-energy plant on day-ahead electricity and heat market is analysed. It is shown that introducing heat market increased needed gate-fee on the 
yearly level over the expected levels. Therefore, it can be concluded that the proposed approach can make projects of otherwise questionable feasibility more attractive.

\section{KEYWORDS}

Waste-to-energy, Combined heat and power, District heating, Power market, Dynamic heat market, Waste management legislation

\section{INTRODUCTION}

A large generation of waste per capita, out of which over a quarter is Municipal Solid Waste (MSW), classifies waste management (WM) as one of the core issues in sustainable development of EU regions. This problem is even more emphasized in urban and metropolitan areas with higher population density. With increasing population, energy consumption also increases. For that reason, urban energy systems have been analysed in many previous research papers. Urban solutions for district heating (DH), the data, and technologies, have been recently discussed in [1]. For such urban applications, optimal planning methods have been elaborated in [2], with the case of Russia. Relevant is also the study of the integration of high share of renewable energy sources [3], which stipulated that energy-only markets need to be addressed for the correct price signals and the flexible measures are of the key relevance for the high RES integration. In this context, flexible WtE CHP plant is a relevant factor in two energy markets: electricity and heat market. Therefore, integration of waste and energy systems represents the logical path in the sustainable development of regions. The importance of the usage of local energy sources in local energy systems, as well as their positive influence on the overall EU energy system, is emphasized in Heat Roadmap Europe [4],[5]. In this study, waste was classified as one of the primary heat sources in district heating systems (DHS). While waste and its energy recovery may seem as 
an ideal energy source for usage in urban areas, EU has identified the material potential of waste, which can be utilized through its material recovery. The first step in this direction was taken by Waste Framework Directive [6] which sets waste hierarchy by which primary step for recovery of produced waste is recycling (material recovery), while energy recovery is subordinated to it. A step further in the direction of material recovery was made by the Circular Economy Package [7] which defines more rigorous goals by increasing the share of MSW, which needs to be primarily separated and prepared for material recovery. These legislative changes have a great influence on waste quantities that are available for usage in waste-to-energy (WtE) based systems [8]. These changes in WMS can put feasibility of incineration-based $\mathrm{WtE}$ systems in question as burnable waste quantity decreases. This problem can be compensated by the introduction of new fuels such as biomass. Woody biomass, agricultural and forest residue [9], as well as biomass from short rotation coppice grown on unused agricultural land [10], showed great potential for use in energy systems and sustainability. Efficient use of locally available biomass was analysed in [11].

The use of biomass in WtE DH plant has proven to be a viable practice, as well as in cocombustion regime and as the use of mixed wastes (MW) for base load and biomass for peak load coverage [12], but time changes in waste quantity are not tracked. Use of WtE in conjunction with energy storage in variable electricity pricing environment, on industry scale, has been analysed and proven to justify a higher establishment cost of WtE [13].

During the lifetime of the WtE DH projects, a "business as usual" way of planning the waste incineration implies a constant increase of MSW quantity with a uniform quality. This is connected with increasing waste generation due to the growth of population and standard of living. This trend was already described by Kuznets curve hypothesis (EKC) which claims 
that economy growth (that can be defined by income per capita) has a negative impact on environment to a certain point after which environmental impact is reducing. This hypothesis was also adapted to MSW and called waste Kuznets curve hypothesis (WKC) and proved that household MSW generation per capita income also follows this correlation [14]. Also, this threshold was already reached by one part of the households/provinces in Japan [14] and Italy [15]. This trend shows that solving waste problem by building new waste disposal facilities can become unviable because increasing tendency in the MSW generation will come to an end. Furthermore, waste policies and instruments that encourage waste prevention can further decrease waste generation [15]. In the EU, the absolute decoupling trend is not present, but the elasticity of waste generation to income drivers is lower than in the past which indicates relative decoupling [16]. Also, current policies do not provide incentives for waste prevention, which will have to change. The introduction of new WM solutions, oriented to the reduction of waste production, re-using and recycling, reduces the amount of waste that needs to be disposed of [17]. The latter effect increases with time and can be viewed as a hazard for the feasibility of WM projects [8]. These effects are emphasized in new EU member states which have to quickly implement new WMS to achieve EU legislation goals but these systems also need to be economically sustainable. This should be done without drastically increasing the price of waste collection for the general population, as it would undermine waste collection system and cause problems such as illegal waste dumping. Therefore, the system needs to be designed to restrict volatility of gate-fees for waste treatment.

Reviewed literature did not sufficiently analyse time change of waste quantity and composition under the influence of WMS changes and its impact on WtE plants. Moreover, only in one paper [8] different ways of compensation of reduced waste quantities are analysed but the influence of secondary separation of waste was not considered. Furthermore, in [8] and [18] economic analysis of the operation of waste incinerators was considered, but their 
overall efficiency is rather low because of the emphasis on electricity generation. Also, in

124 these papers the influence of gate-fee change was analysed only through arbitrary sensitivity analysis without consideration of the influence of other parameters on gate-fee value. Papers that analysed co-combustion of biomass with other fuels such as [19] did not deliberate big

127 involuntary fuel substitution to sustain economic viability. The contribution of this work can 128 be found in viability analysis of this possibility. In another part of this work, the focus was 129 given to the market operation of considered facility. The influence which electricity grid 130 tariffs have on flexible power to heat application was investigated in [20], but more research 131 was done in the field of the possibility of plants operation on the open electricity market 132 [21],[22]. As for the heat energy market, it is still in its infancy as most of the DHS are in 133 public/municipality ownership. However, even in this segment, diversification of ownership is 134 undergoing [23] which inevitably fosters the establishment of heat markets. Open DHS 135 operation was already analysed [24] which consequently led to the analysis of waste 136 incinerator operation on both energy markets in this paper. Upon the possible development of 137 the dynamic heat market in Denmark, WtE plants could face the economic problems as they 138 would not have guaranteed access to the DH market anymore. In addition, a local WtE plant 139 can expect partial fuel switch in the foreseeable future due to a lack of economic feasibility of 140 the waste import [25]. The contribution of this work can also be found in the economic 141 analysis of dynamic WtE which operates on two markets. By introducing new fuel, WtE plant 142 is already switching from operation in regulated conditions without third-party access which 143 means a switch from stable fuel and energy prices to partially market defined fuel prices. On 144 the other hand, after the transition to new WMS, WtE plants need to be ready to compete on 145 open electricity and heat markets. By doing that, a care must be given to the gate-fee 146 volatility, which is unavoidable in open market operations, while at the same time social- 
147 economic component of waste quantity and quality represents one more aggravating 148 circumstance.

149 During the process of defining the case study, big difference in gate-fee values was observed 150 across the EU - up to $176 € / \mathrm{t}$, calculated as a mean value with the addition of waste 151 incineration tax [26]. Also, the difference in national legislations defines a wide range of tax 152 values for different WM and disposal technologies. This is the result of the organization of the 153 WM and its efficiency. Therefore, in this paper case studies of Croatia, where WMS does not 154 meet EU criteria and has one of the lowest recycling rates, and Denmark, which has greatly 155 exceeded the EU goals and is considered to be one of the most advanced systems that even 156 makes extra income from the import and disposal of waste from neighbouring countries. This 157 comparison extends the current knowledge by comparing the two extremes and leads to the 158 conclusion that the investment in thermal waste treatment can be cost-effective in a wide 159 range of configurations of WM system, without constituting an additional financial burden for 160 the municipality or its citizens.

\section{METHODS}

163 The influence of adaptation to new WM legislation on WtE plants is tracked by analysing 164 gate-fee volatility. Also, a method for adapting to expected changes in fuel supply of only planned WtE plant in Croatia and its management is proposed. To compensate for reducing

166 the amount of primary fuel (waste), the share of secondary fuel is gradually increased until the

167 final fuel shift is achieved. Fuel substitution is guided by waste amount prognosis in the 168 analysed time period. This trend is pronounced in all new EU countries, which in the next couple of years have to invest a great effort to implement primary separation into WMS.

170 Changes in the waste collection are expected in order to achieve EU goals gradually, but they 
171

172

173

174

175

176

177

178

180

181

184

cannot solve the waste disposal problem completely, so other ways to tackle this problem are explored. Implementation of other technologies, such as Mechanical Biological Treatment (MBT), is expected to further reduce the quantity of waste available for energy production.

To analyse these changes, production of MSW in the future years is needed to be forecasted. Future waste generation data were adapted from WM, literature or, where these data were not available, by usage of the LCA-IWM prognostic model [27]. In the novel model, the forecast of MSW waste generation and composition on the basis of actual data and a wide range of socio-economic data was taken into account. Also, legislation goals which define forecast boundaries were considered. Output data were structured as overall waste per fractions with and without MW fraction separately reported so all streams can be calculated as well as MW composition. The possibility of waste decoupling was not taken into account, as it was not expected and modelled in long-term projections. Changes expected due to intervention in the WMS were also tracked. LHV of waste were calculated by using the chemical composition of each waste fraction [28] through Mendeliev equation - Equation 1:

$$
L H V=4.187(81 C+300 H-26(O-S)-6(9 H+W))\left[\frac{\mathrm{kJ}}{\mathrm{kg}}\right]
$$

where $\mathrm{C}, \mathrm{H}, \mathrm{O}$ and $\mathrm{S}$ represents the share of corresponding chemical elements and $\mathrm{W}$ represents water share. The calculation of average LHV of mixed municipal waste is based on the calculated LHV of each fraction and physical composition of MW.

When existing WMS did not satisfy set goals, new WM scenarios were developed. The second scenario introduced MBT plant and is based on primary separation of waste, incineration, and MBT. All produced MSW, with the corresponding LHV, enters the incinerator only in the case of meeting legislation goals by source separation alone. Comparison of both scenarios for the case of legislation adaptation is shown in Figure 1. 
195
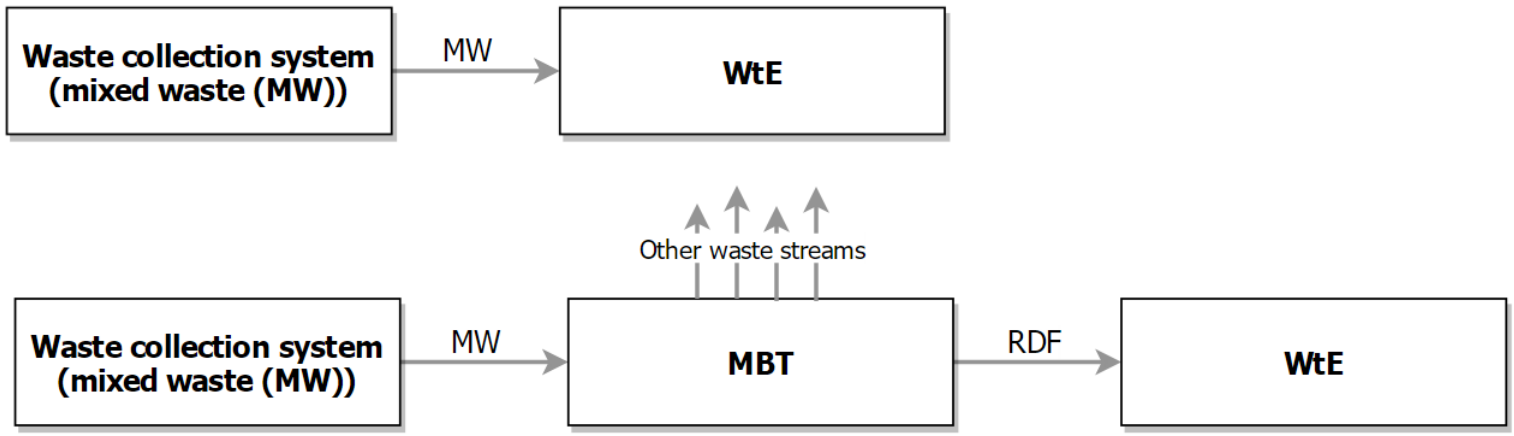

Figure 1. Comparison of the scenarios Without MBT and With MBT

\section{Process flow data for MBT plant, which is introduced in scenario With MBT were adapted} from the literature data [29]. As shown in Figure 2, MBT plant separates mainly bio-waste, metals, and glass, from the MW stream, which are prepared for material recovery processes. Another separated waste stream is Refuse-Derived Fuel (RDF) which is mainly composed of burnable fractions - paper and plastics, while the rest is unusable waste which is landfilled.

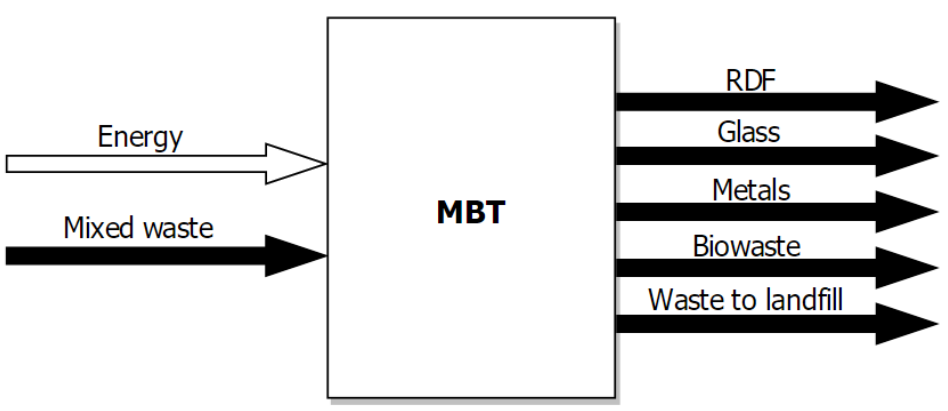

Figure 2. MBT process flows data

207 Waste components which are separated for material recovery do not contribute to the heating 208 value of mixed MSW, so RDF stream's LHV is expected to increase. Quantity wise, this 
scenario further reduced available waste quantities for incineration and left space for 210 introduction of second fuel.

211 To analyse the effect of legislation influenced waste reduction, as well as possible benefits 212 from proposed compensation with secondary fuel, a gate-fee volatility analysis was 213 conducted. The economic analysis was based on the case dependent conditions - national 214 legislation as well as rules and regulations for system operation. The analysis tracked the 215 minimum needed gate-fee to equalize annual cash flow to zero. This way of operation of 216 municipal utility plants is logical because it is built with public funds to provide public 217 service, not to make a profit. The operation of municipal facilities without generating a profit 218 is regulated in some countries by local or national legislation. Example for this is Denmark, 219 where this is regulated at the national level.

220 For analysing volatility of gate-fee due to the operation on energy markets, the case of 221 Denmark facility is chosen because nationwide adaptation to EU waste legislation has already 222 been done. This analysis was performed to investigate the influence of operating the WtE 223 plant on both, electricity and heat markets. To interpret results, two scenarios were 224 constructed, the first one that analysed WtE plant operation on electricity market alone and a 225 second one that analysed its operation on both markets.

226 In the first scenario analysis of WtE plant operation on only one energy market, i.e. the el-spot 227 day ahead market, was carried out. In this case, the heat was assumed to be sold within the 228 municipality under the regulated conditions, without the third-party access.

229 For the second scenario analysis, the operation of the plant on two markets was assumed, an 230 electricity market and a district heat day-ahead market. This case study was carried out in 231 order to assess the prospects of the operation of the WtE plant on the dynamic heat day-ahead 232 market that would operate on a similar principle as the electricity day-ahead market. As the 
233 heat day-ahead market is non-existent in Sønderborg, its hourly demand-supply curve was

234 simulated in Matlab, based on the heating production plants' hourly marginal costs. A similar 235 approach was adopted for the simulation of the heat day-ahead market for the Espoo city in 236 Finland [19].

237 Marginal price of plants was calculated using the Equation 2:

$$
M P=\operatorname{var}_{O \& M}+f u e l / \eta+\text { tax }_{\text {fuel }}-\text { electricity }_{\text {income }}-\text { feed_in }_{\text {premium }}
$$

$239 M P$ denotes marginal price of heat generation in each hour for each heat generation plant and

240 has the unit [€/MWh heat]. Variable operating and maintenance cost is denoted as var $_{O \& M}$, fuel 241 cost and efficiency as fuel and $\eta$, while tax $_{\text {fuel }}$ denotes tax imposed on the use of fuels for 242 energy generation purposes. CHP plants generate income from electricity sales on power el243 spot day ahead market and this income is represented by the electricity $_{\text {income }}$ term while 244 waste CHP plant is also eligible for feed-in premium which is represented by the

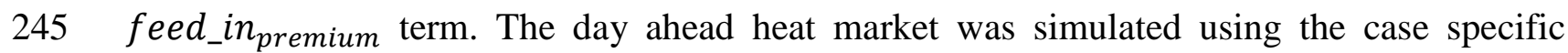
246 marginal heat generation costs of plants.

\section{CASE STUDY}

249 In order to investigate previously discussed changes in WMS and problems associated with 250 them, the case study was created in which two cases were analysed: a potential project of 251 incineration plant in Zagreb, Croatia, as the facility which is faced with upcoming challenges 252 caused by harmonisation with EU waste legislation; and a case of the existing WtE plant in 253 Sønderborg, Denmark, which is already operating on electricity market and faces the prospect 254 of operating on both heat and electricity day ahead markets in the future. 


\subsection{Case of the Sønderborg municipality}

256 The case of Sønderborg was used for market coupling analysis. Two scenarios were analysed 257 - one based on the operation on electricity market (One energy market) and the second one, 258 based on the operation on both electricity and heat markets (Two energy markets). DHS of the 259 municipality of Sønderborg are well described in [30].

260 In Sønderborg municipality, approximately 160,000 tonnes of waste is collected every year 261 out of which $45 \%$ is a household waste [31]. Waste is collected as separated waste streams 262 and used for the production of electric and heat energy in incineration plant or used for 263 material production, landfilled or processed in special treatment plants. In $2012,74 \%$ of 264 generated waste is collected for recycling. By municipal plans, these waste quantities are 265 expected to grow as it is shown in Figure 3.

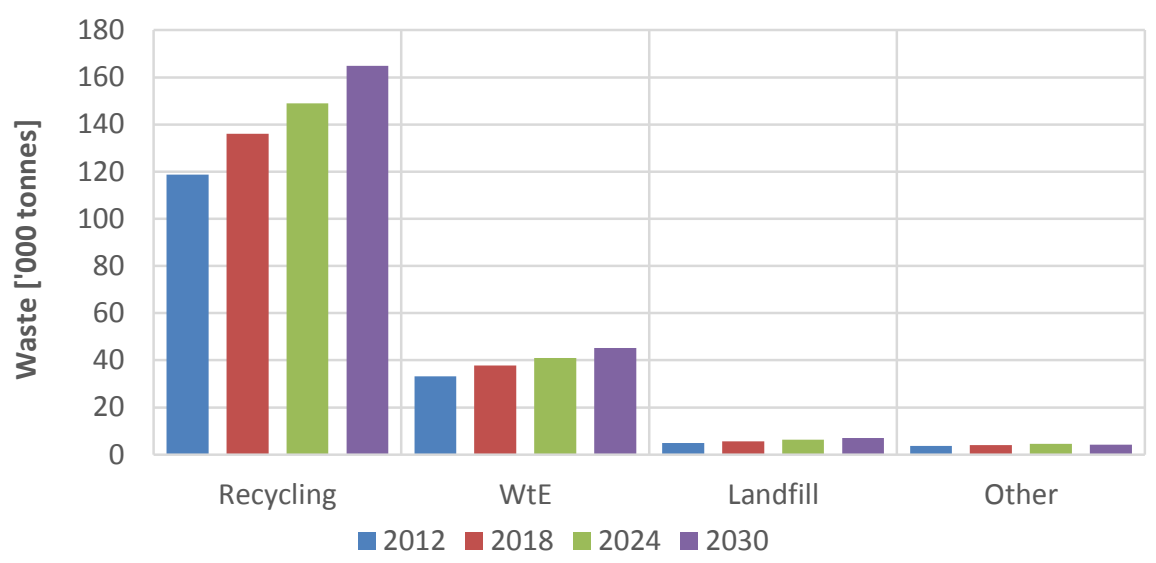

Figure 3. Waste quantities per disposal technologies - Sønderborg

Data for the years 2012, 2018 and 2024 were taken from existing plans [31], while 2030 data were obtained by linear extrapolation, as previous data showed linear time dependence. It was observed that waste quantities for all treatments are expected to increase. 
273 Waste incineration CHP plant is a part of DH network in Sønderborg [32]. The plant is

274 designed as combined cycle cogeneration plant with the conversion of waste energy in the 275 steam cycle. Gas turbine waste heat is utilized for water pre-heating. It was designed to use $27670 \%$ of natural gas and $30 \%$ of waste's energy but that ratio dropped to $0.3 \%$ for gas and $27799.7 \%$ for waste in 2013. Also, the plant has achieved a gross efficiency of $90.5 \%$ in these 278 new conditions and produced 160,148 MWh of heat and 36,069 MWh of electricity from 279 waste with average LHV of $11.2 \mathrm{MJ} / \mathrm{kg}$. The amount of treated waste is 69,630 tonnes from 280 which 33,258 tonnes is from Sønderborg municipality while the rest was imported from 281 Aabenraa municipality and supplemented with waste imported from England and Germany up 282 to the maximum capacity of the plant.

283 Because of the lack of its own waste to fully utilize WtE plants, Denmark has been steadily 284 increasing its waste import from the UK. Sønderborg WtE plant also utilizes imported waste 285 as one part of the full supply. In general, the Danish plant can expect a gate-fee between 27 to $28640 € / \mathrm{t}$ of waste (depending on the season and the quality of the waste), after the costs of 287 transportation and different fees are taken into account [33]. The gate-fee for the waste 288 collected in Denmark is $27 € / \mathrm{t}$ and it is the lowest gate-fee in Europe [34],[35]. Current 289 incineration tax is approximately $44 € / \mathrm{t}$ and this rate was used for both case studies. On top of 290 the gate-fee that the $\mathrm{WtE}$ plants receive, there is a feed-in premium of $0.01 € / \mathrm{kWh}$ of 291 electricity sold to the market [34].

292 In the first scenario, One energy market scenario, the case of Sønderborg WtE plant operating 293 only on one energy market is analysed. The plant is operating on the el-spot day ahead 294 market, while the heat was assumed to be sold within the municipality under the regulated 295 conditions, without the third-party access. This case study represents the current operating 296 scheme of the plant in Sønderborg, as well as the case for most of the DH operators in 297 Denmark. WtE plants are owned by municipalities in Denmark, and they are not allowed to 
operate with profits; they can only recover their operating costs and investments [35].

299 Furthermore, the project time needs to be matched with the anticipated lifetime of the energy

300 plant. For the latter reason, a project lifetime of 20 years has been assumed, based on the

301 technical data available [36]. According to Energinet.dk's recommendation (Danish power

302 and gas TSO), a real discount rate of $4 \%$ was adopted [37].

303 For the second scenario, Two energy markets scenario, a day-ahead heat market had to be 304 established as no such market exists in the municipality of Sønderborg currently. It was 305 simulated using the marginal heat generation costs of plants obtained from the figures 306 presented in Table 1.

Table 1. Costs used for establishing marginal heat price offers [36]

\begin{tabular}{ccccccc}
\hline & $\begin{array}{c}\text { Heat } \\
\text { capacity } \\
{[\mathbf{M W}]}\end{array}$ & $\begin{array}{c}\text { Electric } \\
\text { capacity } \\
{[\mathbf{M W}]}\end{array}$ & $\boldsymbol{\eta}_{\mathbf{e}}$ & $\boldsymbol{\eta}_{\text {total }}$ & $\begin{array}{c}\text { Variable cost } \\
{\left[\mathbf{\epsilon} / \mathbf{M W h}_{\text {heat }}\right]}\end{array}$ & $\begin{array}{c}\text { Fuel cost } \\
{\left[\boldsymbol{\epsilon} / \mathbf{M W h}_{\text {fuel }}\right]}\end{array}$ \\
\hline Waste CHP* & 20 & 4.5 & 0.18 & 0.98 & 4.2 & -8.68 \\
Gas CHP* & 40 & 53 & 0.5 & 0.94 & 2.1 & 32.71 \\
Gas boilers & 100 & - & 0.96 & & 5.4 & 32.71 \\
Solar heating & 6.1 & - & 1 & & 1 & 0 \\
Bio-oil & 5.4 & - & 0.95 & 5.4 & 28.81 \\
$\begin{array}{c}\text { Geoth.+Wood } \\
\text { boiler** }\end{array}$ & 12.5 & - & 1.35 & 5.4 & 28.81 \\
\hline *Income from electricity sales on el-spot day-ahead market was subtracted from the heat marginal price offer on
\end{tabular}

309 the day-ahead heat market. These values were different for each hour depending on the marginal electricity price. Hence, they are not represented in this table but they can be downloaded from www.nordpoolspot.com

311 website, for the year 2015, DK-West area.

$312 * *$ Geothermal heat coupled with absorption heat pump driven by biomass for heat generation. Modeled as 313 biomass boiler with $\eta=135 \%$ as the geothermal heat was considered to be free.

314 Gas is also taxed when used for energy production purposes at the rate of $27.7 € / \mathrm{MWh}_{\text {fuel }}[38]$.

315 Average electricity price development on the el-spot market until 2030 was adopted from 316 [37]. 
317 Recap of all the technical and economic data used for feasibility calculation of WtE plant in

318 both cases is presented in Table 2.

Table 2. Technical and economic data of Sønderborg WtE plant [36]

\begin{tabular}{lrl}
\hline \multicolumn{3}{c}{ WtE plant Sønderborg } \\
\hline Capacity & 4.5 & $\mathrm{MW}_{\mathrm{e}}$ \\
& 19.98 & $\mathrm{MW}_{\text {heat }}$ \\
Total O\&M & 53 & $€ / \mathrm{t}$ \\
Investment cost & $8,500,000$ & $€ / \mathrm{MW}$ \\
Efficiency el & $16.6 \%$ & \\
Efficiency total & $90.5 \%$ & \\
Availability & $92 \%$ & \\
Lifetime & 20 & years \\
Gate-fee & -27 & $€ /$ ton \\
Incineration tax & 44 & $€ /$ ton \\
Feed-in premium & 10 & $€ / \mathrm{MWh}_{\mathrm{e}}$ \\
Real discount rate & $4 \%$ & \\
Inflation & $2 \%$ & \\
\hline
\end{tabular}

321 As per [20] and [25], waste import after the year 2025 will not be economically viable 322 anymore; hence, in this analysis the imported share of waste had to be replaced by biomass.

323 The biomass price for the case of Denmark assumed was $28.58 € / \mathrm{t}$ and was taken from [39].

\subsection{Case of the City of Zagreb}

326 Unlike Denmark, the Croatian WMS is not designed to meet the EU goals. Also, there is no actual WM plan for the City of Zagreb so technologies from WM plan to 2015 [40] were used

328 for definitions of possible scenarios. The scenario Without MBT is based on the primary 329 separation of waste and waste incinerator, while the scenario With MBT added MBT plant.

330 For the WtE plant, as there is no existing incinerator, the same facility as in Sønderborg was 331 assumed for the hypothetical cases. The major difference in WM status and the level of 332 maturity of solutions in this field gives the Croatian case study a fundamentally different 
outcome. In comparison to the Danish case, WM procedures, legislation, and implementation

334 are far from being optimally solved, and Croatia is faced with difficulties to resolve these

335 issues and fulfil the commitment regarding the WM goals [41]. In the City of Zagreb, 300,000

336 tonnes of MSW is collected per year out of which $21 \%$ is separately collected, while the rest

337 is collected as MW. Since there is no actual WM plan, waste quantities in future years were

338 estimated using LCA-IWM prognostic model [28]. Actual and estimated data of separately

339 collected waste fractions are shown in Figure 4.

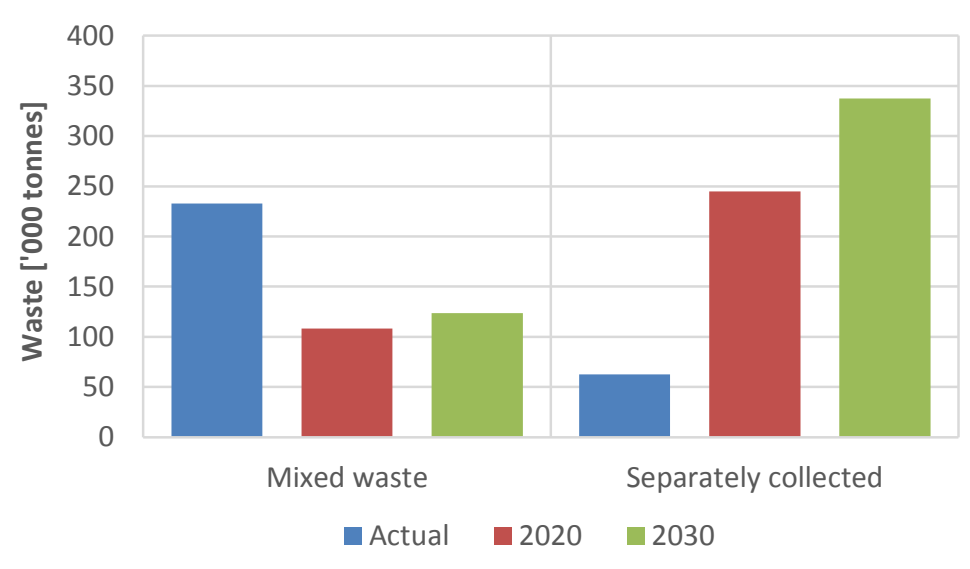

Figure 4. Waste collection quantities

344 Today, separately collected waste is mainly used for material recovery (production of 345 compost and materials), while MW is disposed on landfill Prudinec. Because of this 346 unsustainable practice, two scenarios which, when implemented, can reach EU goals were 347 analysed. These scenarios were developed according to the previously described 348 methodology.

349 Figure 4 shows possible waste collection data, if the primary separation of waste would be 350 introduced and encouraged. The quantity of MW in the forecasted years has dropped by $50 \%$ 351 in such scenario. This represents a challenge for planned WtE plant, but also a good 
opportunity to demonstrate the novel methodology of fuel switch between waste and biomass

353 in the regions where a lot of work is yet to be done in WM.

354 There is no municipal waste WtE plant in Croatia, so there is no expected range of gate-fee 355 value. Therefore this analysis will also help to determine the possible range of gate-fees in the 356 case of the City of Zagreb. Waste incineration in Croatia is not taxed as in many other EU 357 countries. WtE based CHP would be classified as high-efficiency CHP plant and the 358 corresponding fixed feed-in tariff was used [42]. In new legislation WtE plants are recognized 359 as a specific category and market-based tariff, with a proposed feed-in premium, but 360 executive bylaws and regulations are not yet adopted. Furthermore, the heat price is constant 361 as DH price in majority Croatia is considered to be a social aspect and regulated by politics 362 through the government-owned operator. A discount rate of 5.5\% is used which corresponds 363 to discount rate in Public Private Partnerships in energy sector [43]. The analysis was 364 performed on the same time-span as the electricity purchase agreement is signed for -14 365 years.

\section{RESULTS AND DISCUSSION}

368 Based on previously described methods and case specific input data, results for the City of 369 Zagreb and Sønderborg municipality are calculated.

\section{$370 \quad 4.1 \quad$ Fuel data - case of Sønderborg municipality}

371 In the case of the Danish municipality, expected waste increment trends are adopted - no 372 major interventions in WMS are required and the most significant effect on waste generation 373 are socio-economic movements. The impact of this trend on Sønderborg municipality 374 incineration plant is shown in Figure 5. 


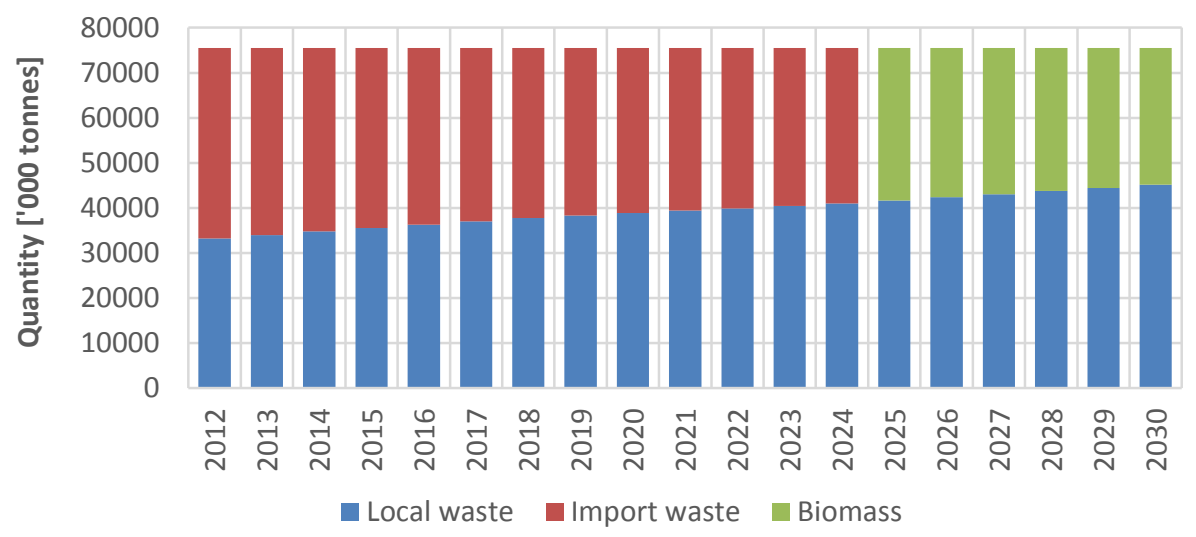

Figure 5. Sønderborg plants fuel ratio

378 Because of the anticipated economic growth, more waste is expected to be locally generated, 379 reducing the need for waste import. It is expected that the import of waste will be profitable until 2020 and probably even until 2025, although with reduced profits [20]. Hence, for both

381 scenarios carried out for the case of Sønderborg WtE plant, a replacement of imported part of 382 waste with biomass was assumed from the year 2025 until 2030 to compensate for the waste 383 decrease. It is important to note here that the biomass used as a fuel for energy purposes is not 384 taxed in Denmark, as it is considered as a renewable energy source, while waste is taxed in 385 order to promote recycling over the waste incineration and landfilling [35].

\subsection{Fuel data - case of the City of Zagreb}

388 The Sønderborg municipality data can be compared with projections for Croatian capital, 389 Zagreb, where WMS needs major interventions. To satisfy EU legislation, projections with 390 rapid implementation of separate collections are performed (Figure 6). 


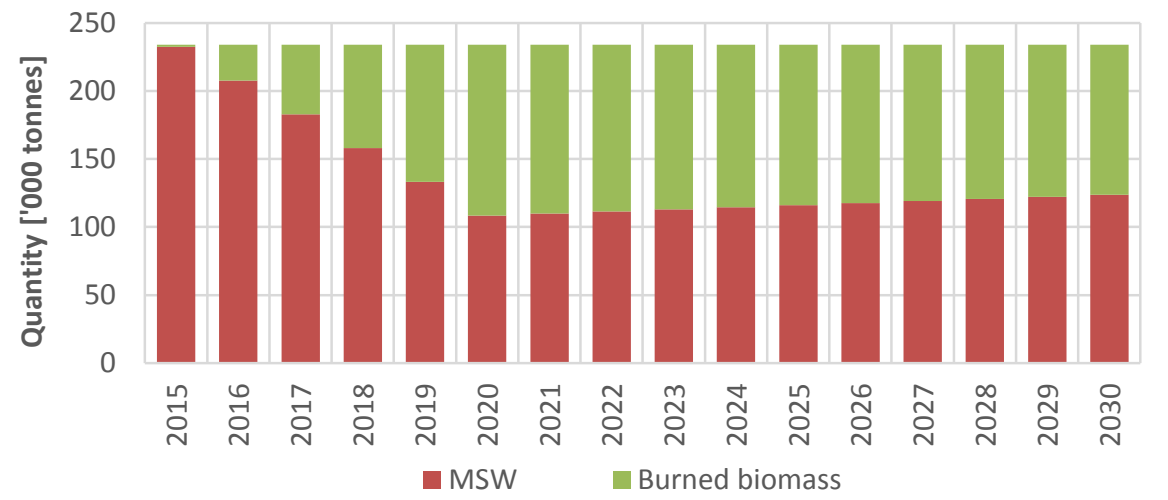

Figure 6. MW quantities - Zagreb

394

395 Until the 2020 quantity of MW is continuously reduced due to an increase of the share of 396 separately collected waste. Rapid implementation of primary separation of waste to fulfil 397 legislation goals for the year of 2020 reduces the quantity of waste that is collected in MW 398 bins and overrides the increase in overall production of MSW due to trends described by 399 WKC hypothesis. After 2020, a slower pace in the development of separate collection system 400 is needed to satisfy legislation goals for 2030, so WKC hypothesis trends in waste generation 401 override decrease in the quantity of MW due to an increasing in penetration and intensity of 402 primary separation of waste. In the period up to 2030, reaching the economic threshold is not 403 expected, so increscent of waste quantity due to WKC hypothesis trends is expected. In these 404 circumstances, the WtE plant has to be planned to satisfy waste disposal needs but also needs 405 to preserve the economic viability of the investment. In this case, the planned size of 406 incineration plant was 233,000 tonnes. As waste quantity decreases, new fuel needs to be 407 introduced - the biomass. Changes in WMS introduced lead to changes in waste composition. 408 As the primary separation of waste decreases quantities of components with low LHV, overall 409 LHV of waste increases. In the second part, after 2020 goals are satisfied, the forecast shows 410 that drop in the relative share of plastics which is the main cause of decrease of LHV in later 411 years. 


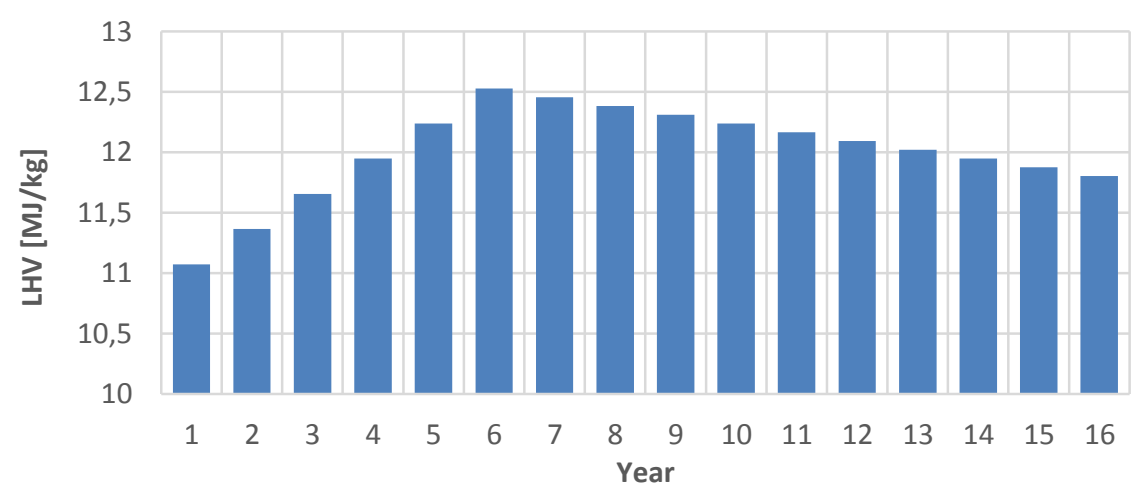

413

Figure 7. LHV forecast - without MBT

415

416 Further development of WMS can further decrease available waste for incineration. By the 417 introduction of MBT, and by sorting of MW, more waste is extracted for material recovery 418 which leads to increased demand for alternative fuels (Figure 8).

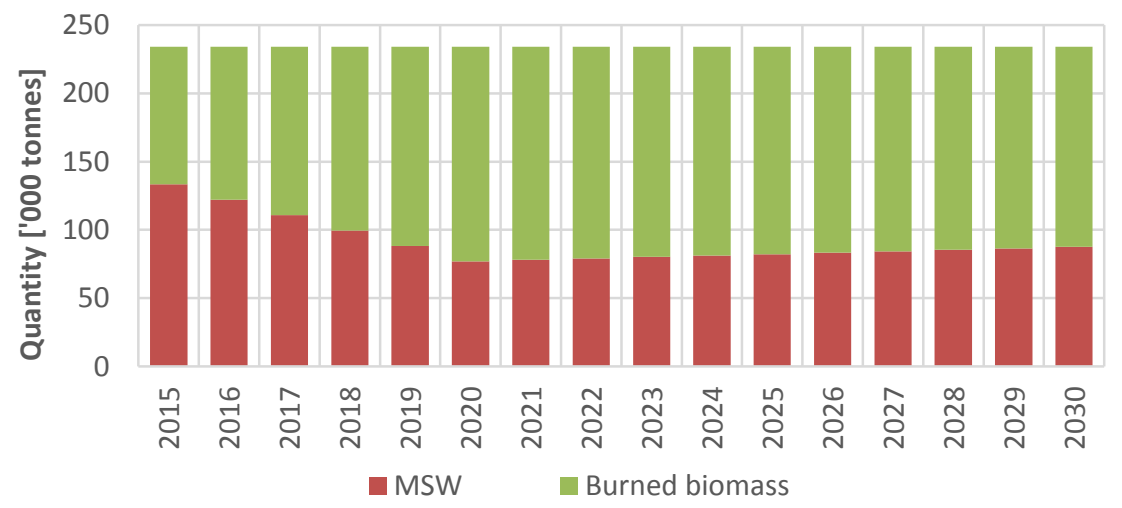

Figure 8. Fuel compensation - with MBT

422 The influence of implementation of MBT in the first year of the analysis on the same WtE

423 plant operation was shown. While separation of waste components decreases waste quantity, 424 it also has an influence on its heating value (Figure 9). 


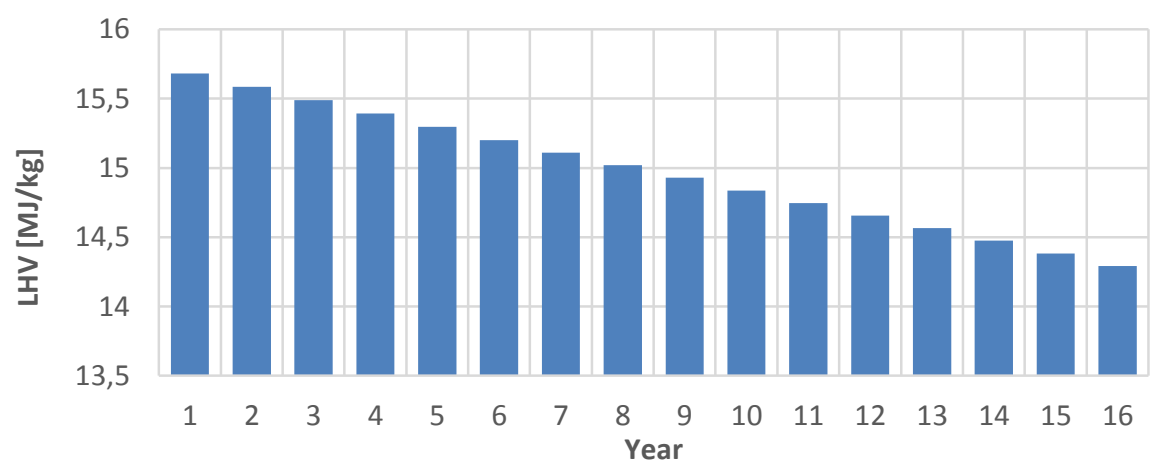

Figure 9. LHV forecast - with MBT

The initial increase in LVH of waste, in comparison with the case without MBT, is due to separation of metals and glass stream, which have no calorific value, and bio-waste stream, which has low calorific value, in MBT facility. The continual decrease of LHV of MW is mainly the result of the increase in primary separation of waste which reduces quantities of paper and plastics, which are not separated in MBT facility and go to RDF stream, in collected MW. Therefore, separated collection of other wastes from waste stream continually reduces LHV of MW on the entrance of the incinerator.

Shown LHVs are calculated only for the MW, while a mixture of waste with biomass would have higher values in the first case, and lower in the second case. This is logical because of constant LHV of biomass in continental Croatia, which amounts to $12.24 \mathrm{MJ} / \mathrm{kg}$ for wood biomass with $30 \%$ of moisture, which depends on a variety of wood species that are used.

439 While in the case of Sønderborg WMS is established and gate-fee prices are defined, in the 440 case of Zagreb they are to be defined. For the initial value of gate-fees, mean European value 441 of $110 €$ per tonne of waste was used for calculation of minimal needed values. The method 442 for determining gate price of biomass at the location was elaborated in [44]. The biomass 443 originates from the capacities of Forestry Offices in the neighbouring counties. The changes 444 in the mean price of biomass on the plant's gate, which is in the range between 32.2 and 37.13 
$445 € / t$ in both cases, show that there is enough biomass for the case examined (Figure 10). These 446 prices were calculated on the basis of the constant price of biomass on the forest road of $32 €$ 447 per tonne and fluctuating transport costs that depend on the distance of the plant from forestry 448 offices from which biomass have to be transported.

450

\section{Zagreb - without MBT}

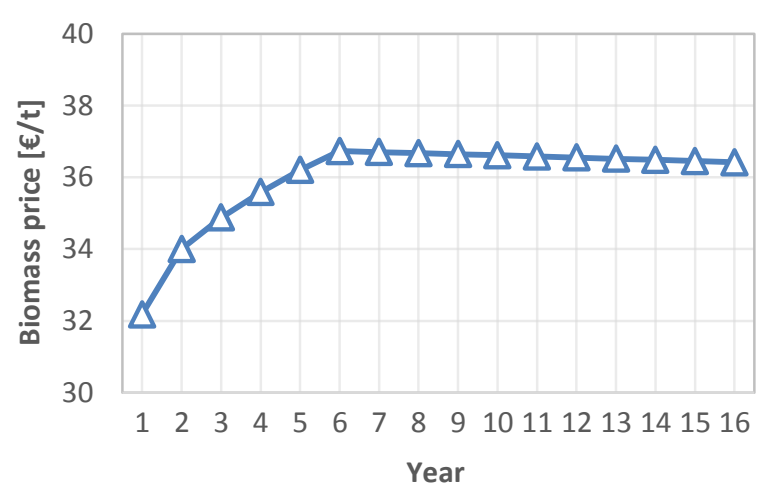

Zagreb - with MBT

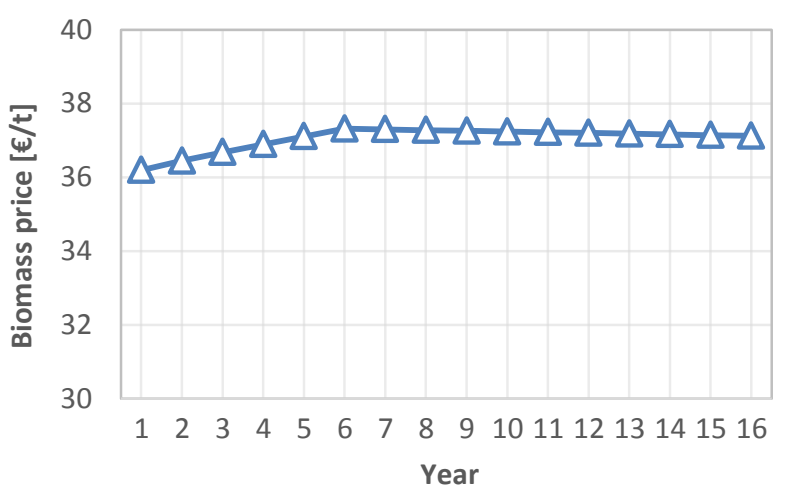

Figure 10. Biomass price

452

The price of biomass increases as needed quantity increases, and vice versa, price decreases only so that it changes with every new forestry office that is included in calculation when the range of biomass collection increases.

\subsection{Economic analysis - Zagreb}

458 All scenarios for the case of the City of Zagreb were calculated on the basis of the same 459 incineration plant whose data for full load are shown in Table 3. 


\begin{tabular}{|c|c|c|}
\hline \multicolumn{3}{|c|}{ WtE plant Zagreb } \\
\hline Capacity & 14.3 & $\mathrm{MW}_{\mathrm{e}}$ \\
\hline & 66 & $\mathrm{MW}_{\text {heat }}$ \\
\hline Total O\&M$M^{3}$ & 51.6 & $€ / \mathrm{t}$ \\
\hline Investment $\operatorname{cost}^{3}$ & $10,700,000$ & $€ / \mathrm{MW}$ \\
\hline Efficiency el & $16.6 \%$ & \\
\hline Efficiency total & $90.5 \%$ & \\
\hline Availability & $92 \%$ & \\
\hline Analysis period & 14 & years \\
\hline Initial gate-fee & -110 & $€ /$ ton \\
\hline Electricity feed-in income ${ }^{1}$ & 73.6 & $€ / \mathrm{MWh}_{\mathrm{e}}$ \\
\hline Heat feed-in income ${ }^{2}$ & 34 & $€ / \mathrm{MWh}_{\mathrm{t}}$ \\
\hline Real discount rate ${ }^{4}$ & $5.5 \%$ & \\
\hline $\begin{array}{l}\text { Taken from reference [42] } \\
2 \text { Taken from reference [45] } \\
3 \text { Taken from reference [5] } \\
4 \text { Taken from reference [43] } \\
\end{array}$ & & \\
\hline
\end{tabular}

462

463 Plant capacity was modelled on the basis of need for waste disposal without changing the existing WMS in 2015.

\subsubsection{Scenario 1 - Without Mechanical Biological Treatment}

Taking into account the influence of gate-fee on the price of waste collection, a yearly gate-

467 fee was modelled as minimum gate-fee that ensures yearly cash flow of zero (after all expenses and investment cost). This also enables comparison of obtained data with

469 Sønderborg case where WtE plant should not operate with a profit. On the same diagram data

470 for the case without and with biomass, compensation can be observed. Also, minimal required

471 constant gate-fee is shown in Figure 11 for the 14 years period. The average gate-fee, which

472 denotes mean price through all 14 years period, in scenario Without MBT is $75.76 € /$, while

473 volatile, which denotes yearly changing gate-fee value, span between 6.21 and $107.69 € / \mathrm{t}$

474 When biomass compensation was introduced, average gate-fee drops to $20.22 € / t$, and volatile

475 is in the range from 6.05 to $26.74 € / \mathrm{t}$ in absolute terms. 


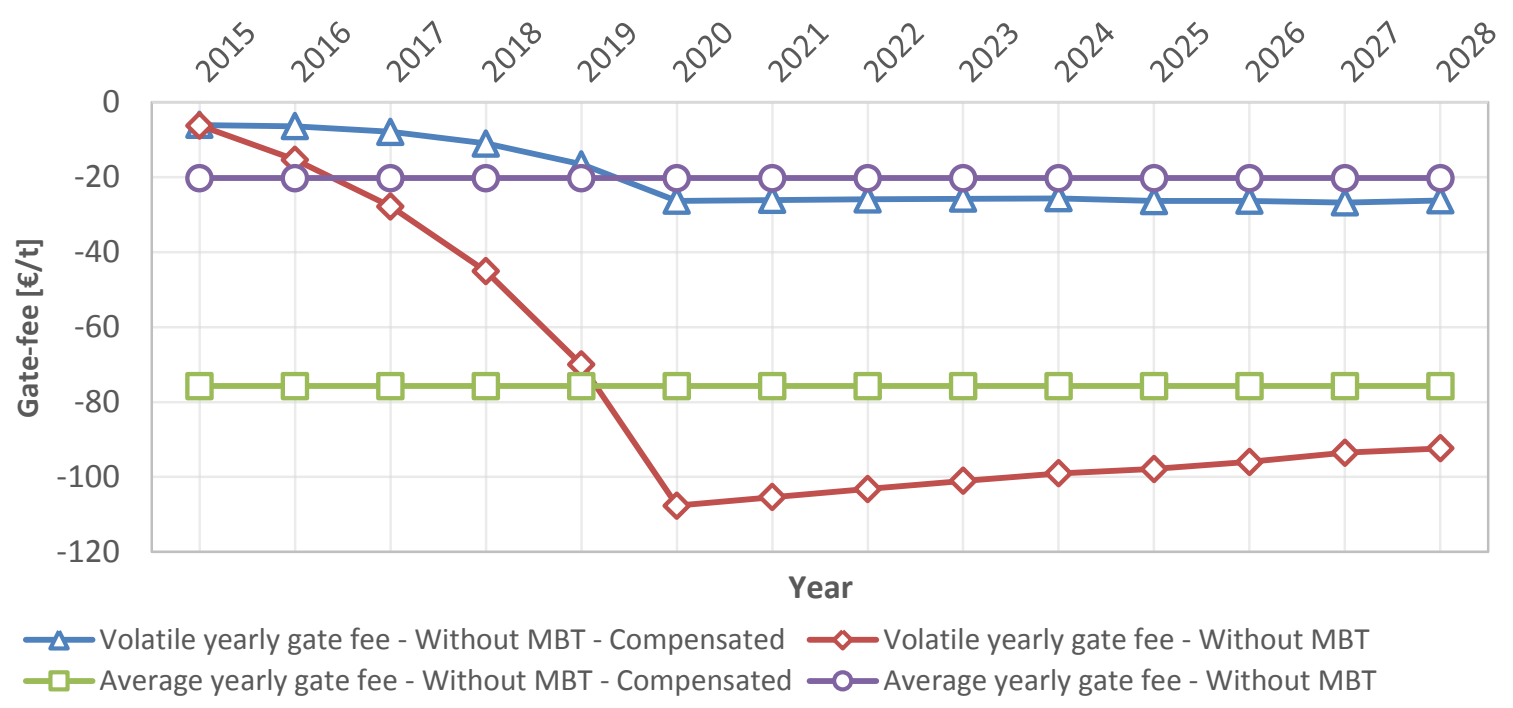

477 Figure 11. Volatile yearly and average gate-fees needed to recover investment and running 478 costs (negative sign denotes that the fee is paid to the generation plant rather than by the

$$
\text { plant) }
$$

480 It can be observed that volatile gate-fee increases rapidly in first years. This is due to 481 decreasing MW amount to 2020. After the 2020 gate-fee volatility is reduced and it's almost 482 constant in compensated case due to an increase in waste amount but a decrease in its heating 483 value. In the not compensated case increase in waste, quantity has much greater influence 484 than the decrease of its heating value so the yearly gate-fee decreases.

\subsubsection{Scenario 2-With Mechanical Biological Treatment}

When MBT plant is introduced in WMS, the quantity of waste is reduced from the first year which increases the gate-fee. Values of gate-fees of this scenario are given in Figure 12. The average gate-fee in scenario With MBT is $-159.11 € / t$, while the volatile span between -48.33 and $-206.94 € / t$. When biomass compensation is introduced, the average gate-fee drops down to $-14.22 € / t$, and volatile is in the range from -25.52 to $19.73 € / t$. 


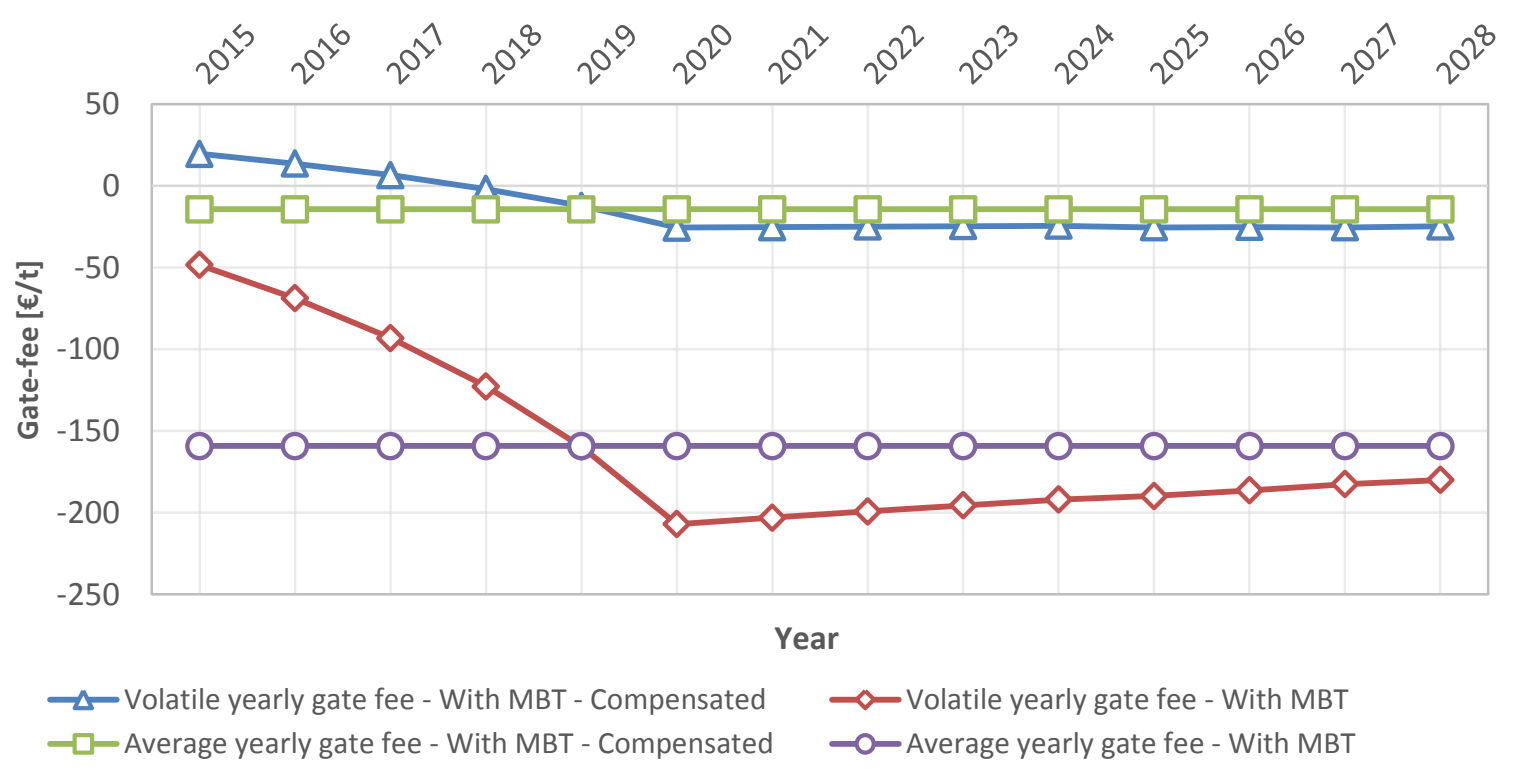

Figure 12. Volatile yearly and average gate-fees needed to recover investment and running costs (negative sign denotes that the fee is paid to the generation plant rather than by the plant)

From Figure 12, it can be noted that even though the gate-fee is vastly increased in comparison with the scenario Without MBT when biomass compensation is introduced the gate-fee needed for economic viability is smaller than in the first scenario. This is due to a big increase in combined heating value of fuel and through greater energy production.

\subsection{Economic analysis - Sønderborg}

501 All scenarios for the case of the Sønderborg municipality were calculated on the basis of the 502 existing Sønderborg WtE plant whose data are shown in Table 2.

\subsection{1 $\quad \underline{\text { Scenario I - One energy market }}$}

504 Taking into account the expected future electricity market prices, as well as the rule that municipality owned WtE plants are not allowed to operate with profit, yearly gate-fees were

506 obtained needed only to recover the investment and the running costs. On the same chart, an average fee until the year 2030 is presented. The average gate-fee could be used if the 
municipality would prefer a less volatile gate-fee price during the lifetime of the plant. These

509 fees can be seen in Figure 13. The average gate-fee for this case was $14.8 € / t$, while the 510 volatile gate-fee was in the span between 9.2 and $28.34 € / t$ in absolute terms.

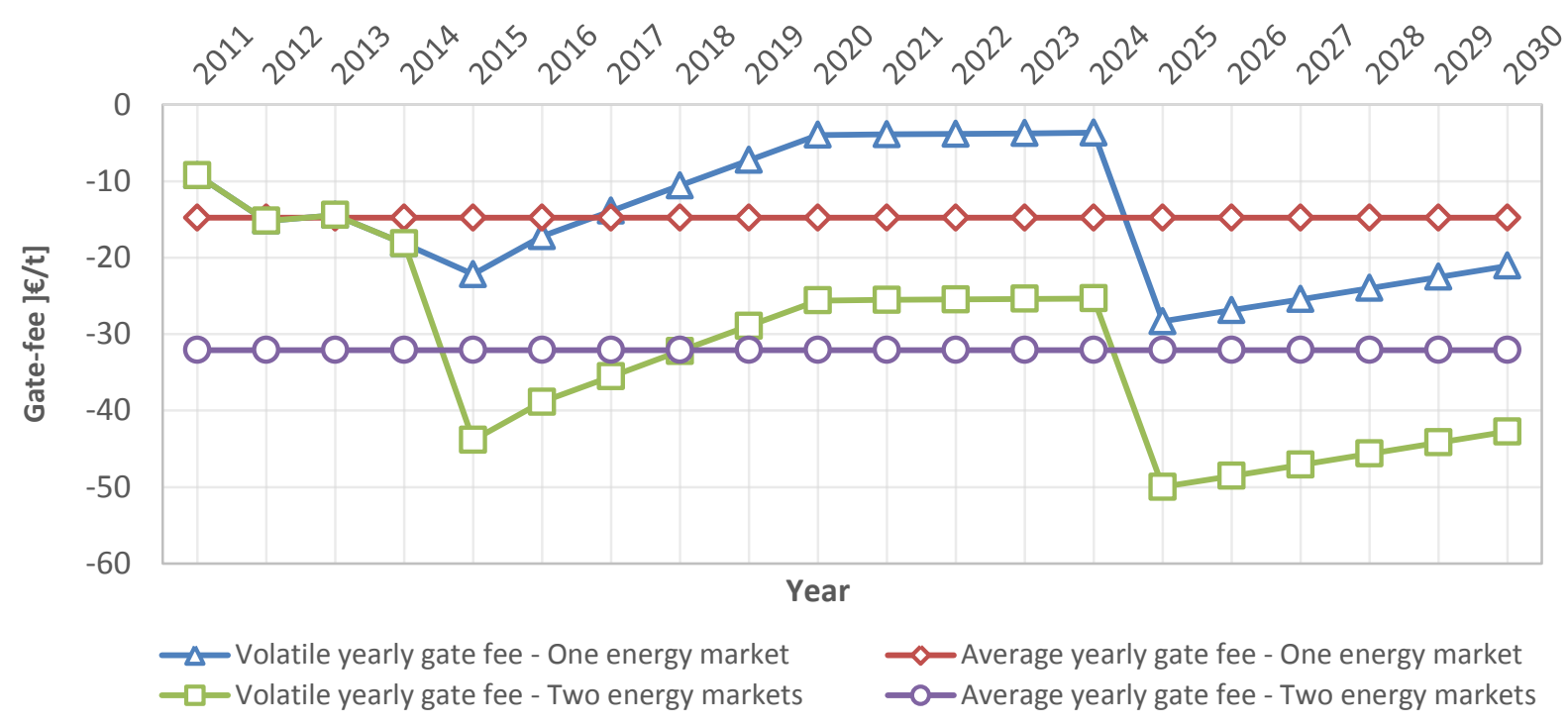

Figure 13. Volatile yearly and average gate-fees needed to recover investment and running costs (negative sign denotes that the fee is paid to the generation plant rather than by the

Up to the year 2015, power prices on el-spot market were decreasing which meant that additional income from the heat market needed to be obtained, in order to recover the running and levelized investment costs of the WtE plant. From the year 2015 on, the average electricity prices are expected to increase, which will reduce the amount of income needed to be recovered from the heat market. The latter allowed the gate-fees to be reduced (in absolute terms).

523 It can be observed that the volatile gate-fee suddenly increases (in absolute terms) in the year 5242025 as this is the year when importing waste will not be profitable anymore. Hence, in the 
year $2025,41.1 \%$ of the fuel consisted of biomass and the rest from the waste collected within

526 the municipality. As the biomass was more expensive than the waste, the gate-fee is needed to

527 be raised in order to recover the biomass cost. The share of waste was then increasing up to 528 the year 2030, in line with the forecasts of steadily increasing amounts of municipal waste, as 529 discussed in the case study section. Using the gate-fees provided in Figure 13 and economic 530 data provided in Table 2, a WtE would have an NPV equal to zero, according to the 531 municipality rules. Thus, it would not operate with a profit nor it would subsidize the heat consumption.

\subsection{2 $\quad$ Scenario II - Two energy markets}

534 Nowadays, heat markets in Denmark are usually operated as monopolies owned by the 535 municipalities. Although the latter can prevent excessive rises in prices due to the regulation, 536 it can also discourage investments in energy efficiency as there is no real incentive for doing 537 it. In order to assess the potential behaviour of the WtE plant on both power and heat markets, 538 marginal prices based heat market was simulated in Matlab, while the power market 539 simulation was carried out in EnergyPLAN. Both power and heat demand were modelled as 540 fixed and known. Heat market was assumed to operate after the power market, i.e. by the time 541 of the bidding on heat day-ahead market CHP producers already knew whether they were 542 dispatched on the power market or not. It was assumed that the plant started to operate on the 543 day ahead heat market in the year 2015.

544 Marginal heat prices obtained from the Matlab, as well as DH hourly demand, can be seen in

545 Figure 14. It can be seen that during the time of high demand the heat prices were high, too. 546 On the opposite, during spring and autumn, when there was a medium demand for the heat, 547 the marginal heat price was volatile. Finally, during the summer season when the demand for 548 heat was low, the heat price dropped accordingly. 


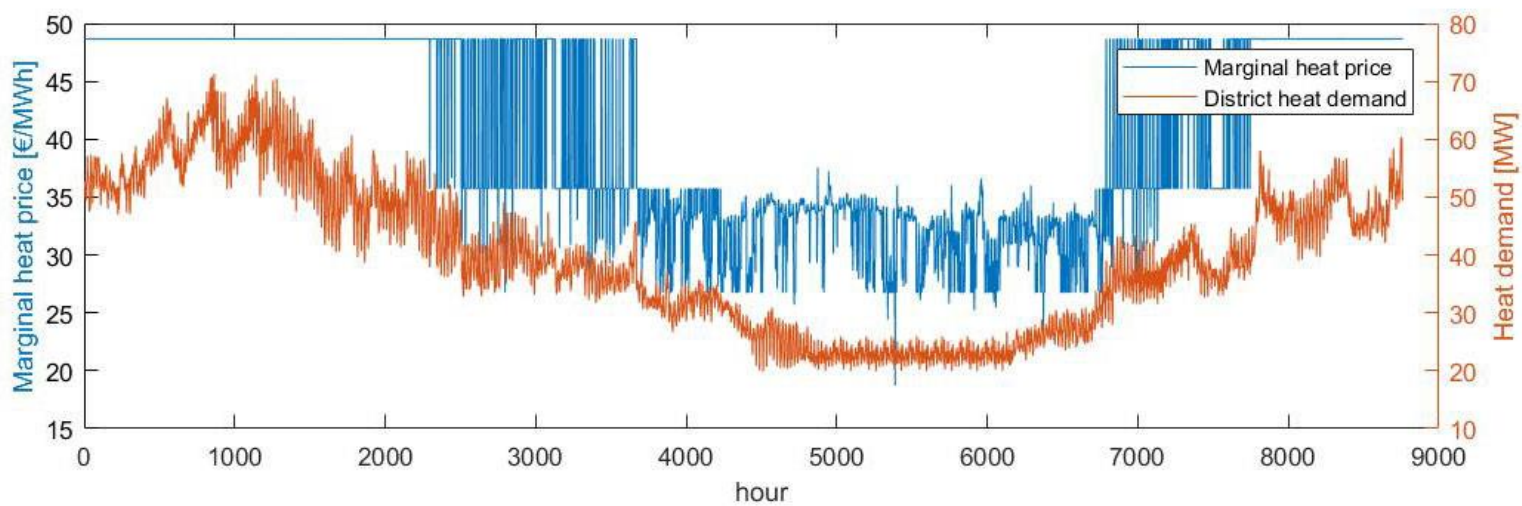

Figure 14. Hourly marginal heat prices (left $\mathrm{Y}$ axis) and district heat demand in the city (right

$$
\text { Y axis) }
$$

Due to the marginal heat day-ahead market, the WtE plant was not dispatched during all the hours of the year on the heat day ahead market. As a consequence, the needed gate-fee to recover investments and running costs during the lifetime of the plant needed to be higher in absolute terms than in One energy market scenario. Dispatching of the WtE plant on the heat market is shown in Figure 15, while volatile and average gate-fees needed are shown in Figure 13, together with the results of the with One energy market scenario.

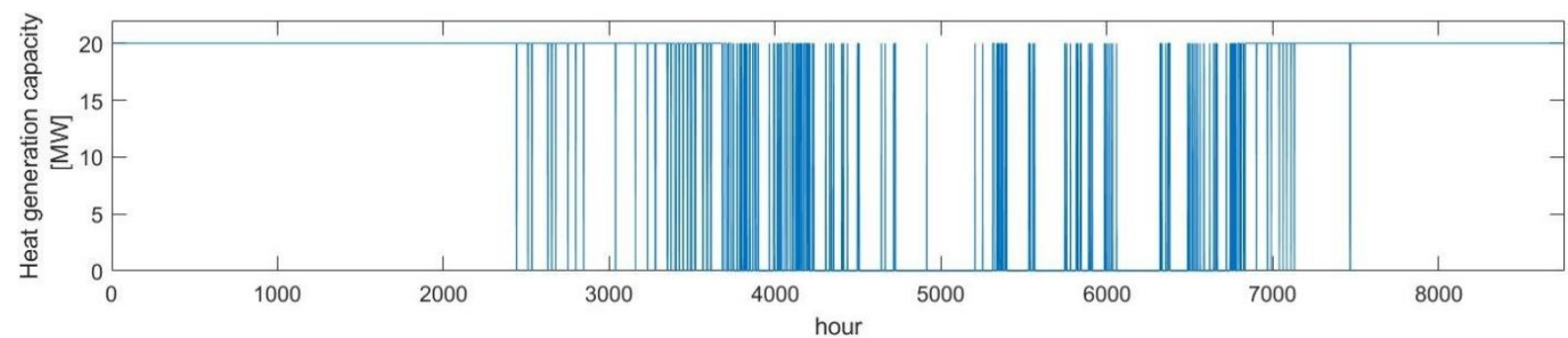

Figure 15. WtE plant operation on the heat day ahead market

By comparing Figures 14 and 15, one can spot that during the time of the high demand the plant was constantly operating on the heat market. However, when the demand started to drop, the WtE plant was not operating in a constant way due to the larger generation of plants with lower marginal cost (solar thermal DH plant) or due to the conditions on the power market. It is important to emphasize here that the second last term in Equation 2 shows that the WtE plant's marginal cost will be very dependent on the achieved power price on the el- 
spot market. If the obtained price is high, marginal heat price of the plant will be low and vice versa.

568 Finally, financial indicators of the regulated market and the marginal based day-ahead 569 markets can be compared. As shown in Table 4, total yearly turnover on the markets is 570 roughly the same in both cases. However, for the WtE plant, operating on both days ahead 571 markets would be less beneficial, as it would receive $22.06 \%$ less income from the heat sales.

572 Table 4. Comparison of the regulated and marginal price-based day-ahead heat markets for the year 2015

\begin{tabular}{cccc}
\hline & $\begin{array}{c}\text { Regulated } \\
\text { (averaged) } \\
\text { prices }\end{array}$ & $\begin{array}{c}\text { Marginal } \\
\text { prices }\end{array}$ & Difference \\
\hline $\begin{array}{c}\text { Yearly turnover heat } \\
\text { sales }\end{array}$ & $14,770,440$ & $14,889,000$ & $0.80 \%$ \\
$\begin{array}{c}\text { Waste CHP heat } \\
\text { turnover }\end{array}$ & $6,841,509$ & $5,332,400$ & $-22.06 \%$ \\
\hline
\end{tabular}

\section{CONCLUSION}

In this work, the analysis was carried out with the aim to analyse the influence of changes that are ahead of WtE plants. Therewithal, compensation for some of these changes is proposed. To test the approach, two WtE plants are taken as case studies, planned WtE plant in new EU member state which needs to fulfil EU legislation WM goals and in one old EU member state

580 which is ahead of EU legislation in the area of WM. In the first case, the case of the City of 581 Zagreb, the operation of planned WtE plant that satisfies needs of the city is analysed until 582 2030. In that period, because of needed WMS changes the majority of its capacity would be 583 unused, less in the case of primary separation of waste alone and more in the case of 584 introducing MBT plant. In these cases, fuel reduction is compensated with biomass which 585 proved to be a sustainable way of alleviating this problem. This way the $\mathrm{WtE}$ plant is moved 
586 from the comfortable zone of regulated prices and put on the fuel market - the biomass

587 market. The influence of this disturbance is tracked trough gate-fee volatility analysis which 588 enabled monitoring of economic viability of municipality-owned plants because of their 589 social-economic influence on the population through the price of the waste collection. This 590 introduction of the WtE plant on fuel market did make this plant economically viable again by 591 reducing needed gate-fee under the value of land-filling gate-fee of $53 € / t$ [46], without 592 incineration tax and with high electricity subsidy. In the second case, the case of the City of 593 Sønderborg, where all EU waste legislation goals are met, the operation of existing WtE plant 594 on day-ahead electricity market and at the same time day-ahead electricity and heat market is 595 analysed and compared. Because heat market does not exist at this time, it is simulated on the 596 principle of the day-ahead electricity market. It is shown that introducing heat market to WtE 597 plants operation increases minimum needed gate-fee on the yearly level and exceeds 598 maximum levels that are expected in Denmark of $40 € / t$. Due to the operation of WtE plant on 599 the heat market, the waste collection price would need to be increased. However, this depends 600 on the price of electricity, because dispatching time is dependent on marginal price which 601 depends on electricity market price in every hour. Nevertheless, such open heat market could 602 decrease heat price which could make it economically neutral on the basis of the municipality. 603 Results of both of this analysis, carried out in completely opposite circumstances, show that

604 WtE plant operation is economically viable during both of these transitions. Also, even 605 though Denmark passed WM transition years ago and adapted to domestically waste 606 reduction through waste import, its WtE plants will nevertheless need to undergo the same 607 fuel switch which is designed for the transition of plants in the new EU member states. 
610 This work has been financially supported by the European Union's seventh Programme

611 (FP7/2007-2013) under Grant agreement no: 608622 (S2Biom project), CITIES project

612 funded by Danish Strategic Research Council (DSF 1305-00027B), Croatian Science

613 Foundation under grant No. DR-5-2014 (Career development of young researchers) and by

614 the European Union's Intelligent Energy Europe project STRATEGO (grant agreement

615 EE/13/650). This support is gratefully acknowledged.

616

$617 \quad 7$ REFERENCES

618 [1] Persson U, Munster M. Current and future prospects for heat recovery from waste in

$619 \quad$ European district heating systems: A literature and data review. Energy 2016;110:116-

$620 \quad$ 28. doi:10.1016/j.energy.2015.12.074.

621 [2] Stennikov VA, Iakimetc EE. Optimal planning of heat supply systems in urban areas.

622 Energy 2016;110:157-165. doi:http://dx.doi.org/10.1016/j.energy.2016.02.060.

623 [3] Auer H, Haas R. On integrating large shares of variable renewables into the electricity

624 system. Energy 2016;115:1592-601. doi:10.1016/j.energy.2016.05.067.

625 [4] Connolly D, Lund H, Mathiesen B V., Werner S, Möller B, Persson U, et al. Heat roadmap Europe: Combining district heating with heat savings to decarbonise the EU energy system. Energy Policy 2014;65:475-89. doi:10.1016/j.enpol.2013.10.035.

628 [5] Persson U, Möller B, Werner S. Heat Roadmap Europe: Identifying strategic heat synergy regions. Energy Policy 2014;74:663-81. doi:10.1016/j.enpol.2014.07.015.

630 [6] European Union. Directive 2008/98/EC of the European Parliament and of the Council. vol. 2003. 2004. 
632 [7] European Commission. $\operatorname{COM}(2015) 614$ final - Closing the loop - An EU action plan for the Circular Economy. 2015.

634 [8] Tomic T, Cosic B, Schneider D. Influence of legislative conditioned changes in waste management on economic viability of MSW-fuelled district heating system: Case study. Therm Sci 2016;20:1105-20. doi:10.2298/TSCI160212114T.

[9] Ćosić B, Stanić Z, Duić N. Geographic distribution of economic potential of agricultural and forest biomass residual for energy use: Case study Croatia. Energy 2011;36:2017-28. doi:10.1016/j.energy.2010.10.009.

[10] Pfeifer A, Dominković DF, Ćosić B, Duić N. Economic feasibility of CHP facilities fueled by biomass from unused agriculture land: Case of Croatia. Energy Convers Manag 2016;125:222-9. doi:10.1016/j.enconman.2016.04.090.

[11] Kalina J. Complex thermal energy conversion systems for efficient use of locally available biomass. Energy 2016;110:105-15. doi:10.1016/j.energy.2016.02.164.

[12] Rentizelas AA, Tolis AI, Tatsiopoulos IP. Combined Municipal Solid Waste and biomass system optimization for district energy applications. Waste Manag 2014;34:36-48. doi:10.1016/j.wasman.2013.09.026.

[13] Islam S, Ponnambalam SG, Lam HL. Energy management strategy for industries integrating small scale waste-to-energy and energy storage system under variable electricity pricing. J Clean Prod 2015;127:352-62. doi:10.1016/j.jclepro.2016.04.030.

[14] Ichinose D, Yamamoto M, Yoshida Y. The decoupling of affluence and waste discharge under spatial correlation: Do richer communities discharge more waste? Environ Dev Econ 2015;20:161-84. doi:10.1017/S1355770X14000370. 
654 [15] Mazzanti M, Montini a., Zoboli R. Municipal Waste Generation and Socioeconomic 655 Drivers: Evidence From Comparing Northern and Southern Italy. J Environ Dev 2008;17:51-69. doi:10.1177/1070496507312575.

657

658

659

660

661

662

663

664

665

666

667

668

669

670

671

672

673

674

675

[16] Mazzanti M, Zoboli R. Waste generation, waste disposal and policy effectiveness. Resour Conserv Recycl 2008;52:1221-34. doi:10.1016/j.resconrec.2008.07.003.

[17] Christensen TH, Simion F, Tonini D, Møller J. Global warming factors modelled for 40 generic municipal waste management scenarios. Waste Manag Res 2009;27:871-84. doi:10.1177/0734242X09350333.

[18] Schneider D, Lončar D, Bogdan Ž. Cost Analysis of Waste-to-Energy Plant. Strojarstvo 2010;52:369-78.

[19] Radovanović PM, Jovanović MP, Erić AM. Opportunities of solid renewable fuels for (co-)combustion with coal in power plants in Serbia. Therm Sci 2014;18:631-44. doi:10.2298/TSCI121210122R.

[20] Kirkerud JG, Trømborg E, Bolkesjø TF. Impacts of electricity grid tariffs on flexible use of electricity to heat generation. Energy 2016;115:1679-87. doi:10.1016/j.energy.2016.06.147.

[21] Perković L, Mikulčić H, Pavlinek L, Wang X, Vujanović M, Tan H, et al. Coupling of cleaner production with a day-ahead electricity market: A hypothetical case study. J Clean Prod 2016. doi:10.1016/j.jclepro.2016.12.019.

[22] Perković L, Mikulčić H, Duić N. Multi-objective optimization of a simplified factory model acting as a prosumer on the electricity market. J Clean Prod 2016. doi:http://dx.doi.org/10.1016/j.jclepro.2016.12.078. 
676 [23] Magnusson D. Who brings the heat???? From municipal to diversified ownership in the

677

678

679

680

681

682

683

684

685

686

687

688

689

690

691

692

693

694

695

696

697 Swedish district heating market post-liberalization. Energy Res Soc Sci 2016;22:198209. doi:10.1016/j.erss.2016.10.004.

[24] Syri S, Mäkelä H, Rinne S, Wirgentius N. Open district heating for Espoo city with marginal cost based pricing. Int Conf Eur Energy Mark EEM 2015;2015-August. doi:10.1109/EEM.2015.7216654.

[25] ENDS waste \& bioenergy. Imported waste worth $€ 147 \mathrm{~m}$ to Denmark 2014. http://www.endswasteandbioenergy.com/article/1323930/imported-waste-worth$€ 147 \mathrm{~m}$-denmark (accessed December 27, 2016)

[26] Bio Intelligence Service. Use of Economic Instruments and Waste Management Performances. 2012.

http://ec.europa.eu/environment/waste/pdf/final_report_10042012.pdf (accessed September 27, 2016)

[27] Boer E Den, Boer J Den, Jager J. Waste management planning and optimisation (LCA IWM). Stutgart: Obidem-Verlag; 2005.

[28] Magrinho A, Semiao V. Estimation of residual MSW heating value as a function of waste component recycling. Waste Manag 2008;28:2675-83. doi:10.1016/j.wasman.2007.12.011.

[29] Abeliotis K. Life Cycle Assessment in Municipal Solid Waste Management. vol. 1. Shanghai: InTech; 2011.

[30] Dominković DF, Bačeković I, Sveinbjörnsson D, Pedersen AS, Krajačić G. On the way towards smart energy supply in cities: The impact of interconnecting geographically 
distributed district heating grids on the energy system. Energy 2017.

699 doi:10.1016/j.energy.2017.02.162.

700

701

702

703

704

705

706

707

708

709

710

711

712

713

714

715

716

717

[31] Sønderborg Municipality. Waste and resource plan 2014 - 2024 for Sønderborg Municipality. Sønderborg: n.d. http://sonderborg.viewer.dkplan.niras.dk/media/648159/a_redegoerelse-pr-26-jan2015.pdf (accessed July 2, 2016)

[32] Sønderborg CHP I / S Annual Report incl. green accounting and environmental statement 1 January to 31 December 2013 n.d. http://www.sonderborgfjernvarme.dk/wp-content/uploads/2016/05/Årsrapport-2014-SKVV.pdf. (accessed June 9, 2016)

[33] B\&W Vølund. $\quad$ Attractive 2014. http://www.volund.dk/News/2014/01/Newsletter/Attraktiv_affaldsimport?language=en (accessed December 27, 2016).

[34] Kirkeby J, Grohnheit PE, Møller Andersen F, Herrmann IT, Karlsson KB. Experiences with waste incineration for energy production in Denmark. 2014.

[35] Reno Sam, Ramboll. Waste-to-energy in Denmark. 2006.

[36] Energinet.dk. Technology data for energy plants. 2012. doi:ISBN: 978-87-7844-940-5.

[37] Energinet.dk. Energinet.dk's analysis assumptions 2014-2035, Update September 2014. 2014.

[38] International Energy Agency (IEA). Energy prices and taxes: Country notes. 2016.

[39] Gregg JS, Bolwig S, Solér O, Vejlgaard L, Gundersen, Sofie Holst Grohnheit PE, Herrmann, Ivan Tengbjerg Karlsson KB. Experiences with biomass in Denmark. 2014. 
[40] Mužinić M, Pašalić G, Martina C, Fundurulja D, Domanovac T. Waste management plan of the City of Zagreb to 2015. City of Zagreb; 2007.

[41] Reichel A. Municipal waste management in Croatia 2013. http://www.eea.europa.eu/publications/managing-municipal-solid-waste/croatiamunicipal-waste-management.

[42] The Government of the Republic of Croatia. Tariff System for the Production of Electricity From Renewable Energy Sources and Cogeneration. 2012.

[43] Centre for Monitoring of the energy sector and investments. The tender documents n.d. http://cei.hr/upload/2014/08/dokumentacija_za_nadmetanje__istra_53e4d853ac327.pdf.

[44] Dominković DF, Ćosić B, Bačelić Medić Z, Duić N. A hybrid optimization model of biomass trigeneration system combined with pit thermal energy storage. Energy Convers Manag 2015;104:90-9. doi:10.1016/j.enconman.2015.03.056.

[45] HEP Toplinarstvo - price list 2016. http://www.hep.hr/toplinarstvo/en/customers/price.aspx. (accessed May 20, 2016)

[46] Zagrebački holding - Podružnica ZGOS. Pricelist 2016. http://www.zgos.hr/UserDocsImages/Cjenik/Cjenik_0402216.pdf. (accessed December $25,2016)$ 